\title{
THE PROTECTION OF SAVANNAS AND ITS EFFECTS ON THE VOLUME OF WOOD, BIOMASS AND CARBON SEQUESTRATION
}

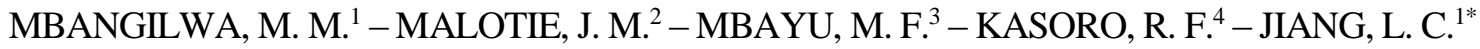 \\ ${ }^{1}$ Key Laboratory of Sustainable Forest Ecosystem Management, Ministry of Education, School \\ of Forestry, Northeast Forestry University, Harbin 150040, P.R China \\ ${ }^{2}$ Post-university Regional School for Integrated Management and Management of Tropical \\ Forests and Territories (ERAIFT), University of Kinshasa, B.P. 15.373 Kinshasa, Democratic \\ Republic of Congo
}

${ }^{3}$ Faculty of Management of Natural and Renewable Resources (FGRNR), University of Kisangani, B.P 2012 Kisangani, Democratic Republic of Congo

${ }^{4}$ College of Resources and Environment Sciences, Jilin Agricultural University, 2888 Xincheng St, Nanguan, Changchun, Jilin, P.R. China

\author{
*Corresponding author \\ e-mail: jlichun@nefu.edu.cn
}

(Received $6^{\text {th }}$ Sep 2019; accepted $25^{\text {th }}$ Nov 2019)

\begin{abstract}
The variation in the productivity (biomass and wood volume) and sequestered carbon of savannas was monitored in Manzozi, Bas-Congo province (Kongo-central) in the Democratic Republic of Congo. Sixteen plots of one hectare each have been set up, eight of which were in the protected savannah and eight in ones subject to fires. The study was limited to ligneous trees and shrubs. The savannah put in defenses is richer in volume of wood $\left(3.6 \mathrm{~m}^{3} / \mathrm{ha}\right.$ against $\left.7.8 \mathrm{~m}^{3} / \mathrm{ha}\right)$; biomass $(29.8 \mathrm{t} / \mathrm{ha}$ vs. 8.2$)$ and carbon $(14.9 \mathrm{t} / \mathrm{ha}$ versus 4.1$)$ than that under fire.
\end{abstract}

Keywords: deferred grazing, shrubs, ligneous trees, Manzonzi, Bas-Congo (Kongo-central)

\section{Introduction}

Tropical savannas and forests are important components of the land carbon sink (Pan et al., 2011; Liu et al., 2015; Ahlström et al., 2015; Trugman et al., 2018). However, their ability to continue sequestering carbon is uncertain (Malhi et al., 2008), due in part to the impact of projected increases in drought frequency and changes in the fire regime on woody carbon stocks (Brando et al., 2014; Trugman et al., 2018). Globally, tropical forests, savannas, and grasslands comprise $\sim 60 \%$ of total terrestrial gross primary productivity (Beer et al., 2010) but are also responsible for over $65 \%$ of global carbon emissions stemming from fire and deforestation (Van der Werf et al., 2010, 2009; Trugman et al., 2018).

Savannas are one of the world's major terrestrial ecosystems, comprising between 10 $\%$ and $15 \%$ of the world's land surface, depending on definition (Scholes and Hall, 1996; Shackleton and Scholes, 2010). Distributed across nearly all the continents, they occur in broad bands between the equatorial forests and mid-latitude deserts. Approximately $50 \%$ of the African continent and parts of Democratic Republic of the Congo are savannas. They are home to over 30\% of the world's population (Solbrig et al., 1991), and consequently experience marked impacts from human activities. Of particular concern are deforestation and land use change activities which reduce or eliminate the biomass of trees and shrubs. This not only alters local nutrient, water and carbon cycles, 
thereby affecting local livelihood options and agricultural productivity, but also adds to global $\mathrm{CO}_{2}$ emissions (Miles and Kapos, 2008; Shackleton and Scholes, 2010).

However, we can also say that savannas are complex ecosystems marked by the coexistence of herbaceous strata and one or more layers shrub and / or tree as a result of the interaction of several environmental factors varied rainfall regimes, role of fire and the breeding (Jacquin, 2010) as well as the nature of the soil. It is also defined as an open grassland formation composed mainly of perennial or annual grasses (Jacquin, 2010). Its vegetation may be purely grassy or scattered with shrubs or trees and varies according to rainfall, soil and anthropogenic activity (Clement, 1982; Manlay et al., 2002).

The Mayombe, of which Manzonzi is a part, is a region where anthropogenic pressure (deforestation, bushfire) has played an important role in the reduction of forest areas and the conversion of the ecosystem. Bush fire has also influenced landscape physiognomy in recent decades and has become a determining factor in the maintenance of savanna vegetation. Savanna ecology and the consequences of fire regime on wood volume, biomass and carbon sequestration is one of the most important issues for savanna management. There are to date few studies dealing with the bush fire effect on productivity in the savannahs. The lack of in-depth studies on this issue makes it impossible to accurately assess the effect of bush fire and the management of its impacts on vegetation. However, in many regions intensive land use is not permanent, leading to a mosaic of land use types with varying levels of woody biomass (Giannecchini et al., 2007; Eaton and Lawrence, 2009) and hence carbon sequestration potential. Consequently, carbon accounting for specific geographic regions needs to be able to accommodate such dynamic changes, benchmarked against relatively un-impacted sites.

The international concern with and modelling of carbon emissions and sequestration requires adequate coverage of locally quantified carbon stocks. However, several authors have commented on the relative dearth of quantitative estimates for dry forests and savannas relative to moist tropical forests (e.g. Salis et al., 2006; Williams et al., 2008), although with exceptions, such as work in the Thicket Biome of South Africa (Mills et al., 2005; Mills and Cowling, 2006; Powell, 2008). Whilst biomass per unit area in savannas is less than tropical forests, the high rates of disturbance through fire and land clearing and their significant global extent, makes it imperative that the carbon stocks of savannas are adequately quantified and reported (Bombelli et al., 2009). This will then provide the basis for more accurate global estimates and predictive allometric equations, thereby bringing substance to the appeal of Lal (2002), namely to facilitate mobilization of provisions of the Kyoto protocol to manage savannas for carbon sequestration benefits through maintenance of existing woody biomass or reforestation. Lal (2002) also suggests agricultural intensification and biofuel plantations as two other approaches to increase carbon pools in savannas and drylands. However, the low rainfall and competition with other land uses limit their viability in many places (Woomer et al., 2004; Shackleton and Scholes, 2010).

Whilst time-consuming work, determination of woody plant biomass relationships with any of a series of morphometric variables usually yields highly significant results, especially after transformation of one or both sides of the dependent and independent variables. The most commonly used independent variable from a variety of vegetation types is stem diameter or stem circumference (Dayton, 1978; Hofstad, 2005; Dias et al., 2006; Salis et al., 2006). Inclusion of tree height sometimes improves the relationship (Chidumayo, 1988; Brown et al., 1989), although not always (Brown et al., 1989). It is also a covariate with stem diameter. Crown diameter, area or volume have also been 
used as the predictor variable by some authors (Kelly and Walker, 1977; Deshmukh, 1992), but generally yield weaker regression relationships than stem circumference, and become very variable in dense vegetation where crown size is constrained (Tietema, 1993; Powell, 2008). Combinations of diameters, height and crown dimensions may provide the best predictive capacity, but are rarely worth the extra time and effort required to measure all three (Hofstad, 2005).

Within the context of the study that we are leading here, our hypothesis is that savannahs exclosure becoming more stable tend to have higher productivity and sequester more carbon. On the other hand, fire savannas would have low productivity and sequester less carbon. The objective of the present work was to evaluate the effects of the protection of savannas subject to the fire regime and the productivity of savannas (biomass and volume of wood) and sequestered carbon. Specifically, it is a question of analyzing and comparing the productivity (volume, biomass), and the carbon content of the savannah woody vegetation put in defense to that of the savannas subjected to the fire regime of different intensity. Also, it is a question of demonstrating the advantages that the conservation of the savannas in the ecological planes in relation to the climate.

\section{Field of study}

The Mayombe climate is tributary of the Atlantic Ocean, influenced by the cold Benguela current and the southeastern trade winds (Lubini, 1997). This cold marine current of Benguela is responsible for the small dry season rains known locally as "masala" (Kapa et al., 1987). These so-called occult rains (De Foresta), are expected towards the end of August, and play the role of compensation of the deficit of water of the ground. There is a dry season (May - September) and a rainy season (September May) with a short dry season of 2 or 3 weeks in February (Quinif, 1986).

The site under study is part of the Mayombe chain stretching from Gabon through Angola (Cabinda) to the Democratic Republic of the Congo (DRC). The chain has Mayombe is a geological structure which includes four stages, the newest upstairs though the west-congo (Lubini, 1997). It is made up of volcanic and metamorphic rocks formed at the middle Precambrian (Quinif, 1986). It includes schisto-grafic and schistocalcareous systems (Lubini, 1997). In addition, shales, quartzites, graphitic rocks, feldspathic sandstones, micaschists, muscovites, amphiboloschists and intrusive rocks are observed. These various rocks have allowed the formation of the various types of soils encountered there. The soil is mostly made up of ferralsols on undefined rocks (Sys, 1960). The rock formations are covered with a layer of surface soils of thickness ranging from $20 \mathrm{~cm}$ to $3 \mathrm{~m}$. These eluvia or colluvium derives from the underlying or surrounding geological basement (Sys, 1960).
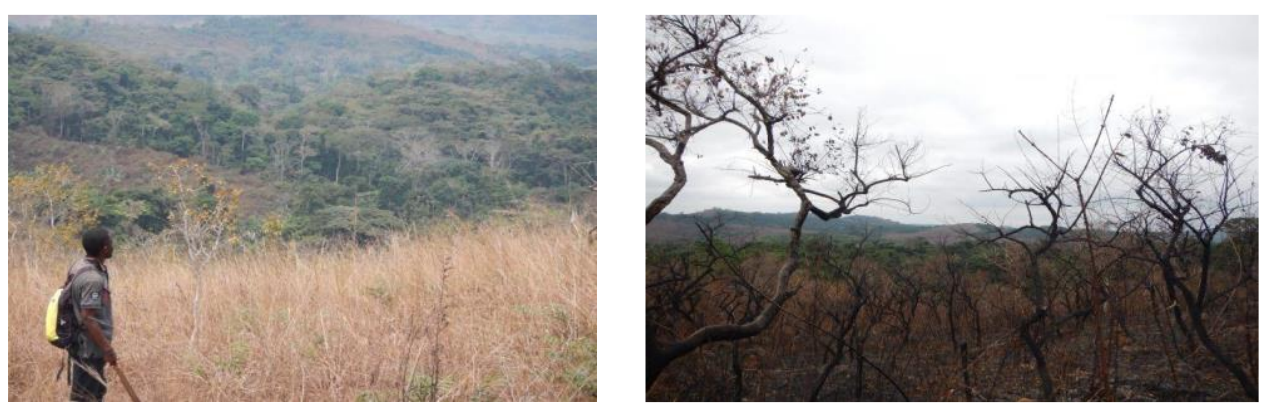

Figure 1. Image of Manzonzi savanna plots around the Luki Biosphère reserve in Bas-Congo (Source: Field investigation) 


\section{Materials and Methods}

\section{Study area and data}

In 2010, WWF proceeded with the opening of the variable-length layons according to the physiognomy of the site to be used for systematic inventories to characterize the large plant formations in this Manzonzi savannah. A total of 101 plots of $80 \mathrm{~m} \times 50 \mathrm{~m}$ each and $20 \mathrm{~m}$ apart from each other were placed there. This device has the advantage of capturing the heterogeneity of the ecological gradients of the environments traversed and of probing the homogeneous superimposed surfaces.

For the present study conducted in April 2018, the system put in place was based on a stratified sampling of plots distributed in the savannah. The selection of firewood savanna (SRF) plots was based on annual fire passage, and populations were consulted for this choice. Plots were placed in a given orientation, indicated by the compass and had the following GPS positions: Pt1: (SMD: 13 ${ }^{\circ} 15^{\prime} 24.2^{\prime \prime}$ North and $5^{\circ} 43^{\prime} 34.2^{\prime \prime}$ South), (SRF: $13^{\circ} 15^{\prime} 06.2^{\prime \prime}$ North and $5^{\circ} 44^{\prime} 56,1^{\prime \prime}$ South); Pt2: (SMD: 13 ${ }^{\circ} 15^{\prime} 24.2^{\prime \prime}$ North and

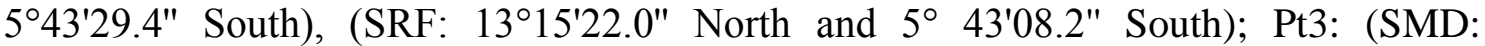

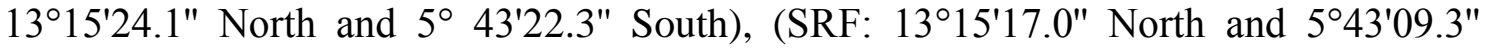

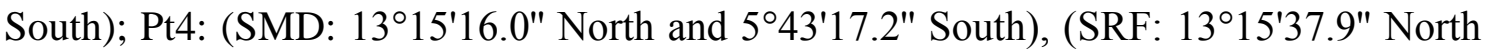

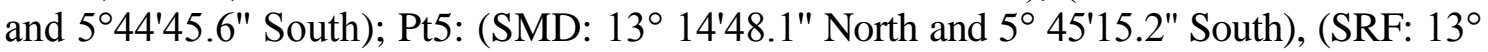

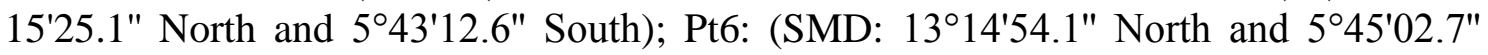
South), (SRF: $13^{\circ} 15^{\prime} 33.1^{\prime \prime}$ North and $5^{\circ} 44^{\prime} 47.1^{\prime \prime}$ South); Pt7: (SMD: 1314'31.6" North

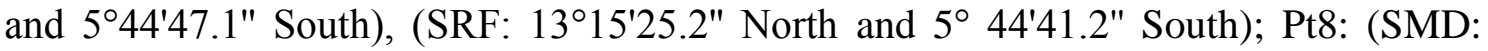

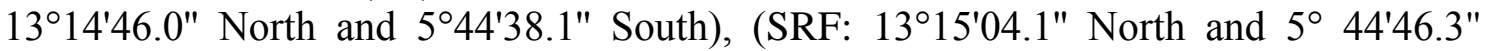
South). Each starting point of the plot is materialized by a stake bearing the number of the parcel of inventory. The distance marking stakes were made from the stems of the small trees harvested on site and were placed every $50 \mathrm{~m}$. Depending on the slope, a certain distance was added in order to have a real horizontal distance corresponding to the length sought for the plots (SPIAF, 2007).

All plots were geo-referenced using a GPS and a tracking was done for the savannah defensive (SMD). The tracking data included in the Geographic Information System (GIS) allowed us to use the ARC GIS 9.2 software to produce the site map under study (Figure 2).

\section{Botanical inventory and data collection}

Eight other plots $(100 \mathrm{~m} \times 100 \mathrm{~m})$ were installed in the savannah and eight others in savannas under fire following the same vegetation. The aim was to ensure the representativeness of the plots (Favrichon et al., 1998; Devineau et al., 1984), their diversity (Dibi et al., 2008), and stratified sampling. The location of the plots took into account the topographic features of the environment, the physiognomy of the vegetation and the fact that they significantly include ligneous plants of different heights. Inside the plots, all the species have been recorded (Favier et al., 2004; Dibi et al., 2008) and all woody trees $\geq 20 \mathrm{~cm}$ measured (Duarte et al., 2006). The use of the ribbon was preferred to the forest compass because of the ease of work and the fact that the circumference gives a better estimate of the volume than that obtained by the compass (Rondeux, 1993).

The height was measured using a $5 \mathrm{~m}$ tall graduated wooden stem for shrubs and or Blum Leiss for trees. For individuals with multiple stems above $1.30 \mathrm{~m}$ or in tuft (case of Nauclea latifolia Smith), all stems are measured and differentiated by letters a, b or c as appropriate. Sea grass samples of species not directly identified in the field were 
collected. The herbarium of Luki and of the Faculty of Science of the University of Kinshasa enabled the identification of our equipment. Each double of the collection has also been deposited. For botanical nomenclature, we followed the system of Angiosperms Phylogeny Group (APG), and also the nomenclature of the RMCA available on www.Metafro.be for synonymy and authors.

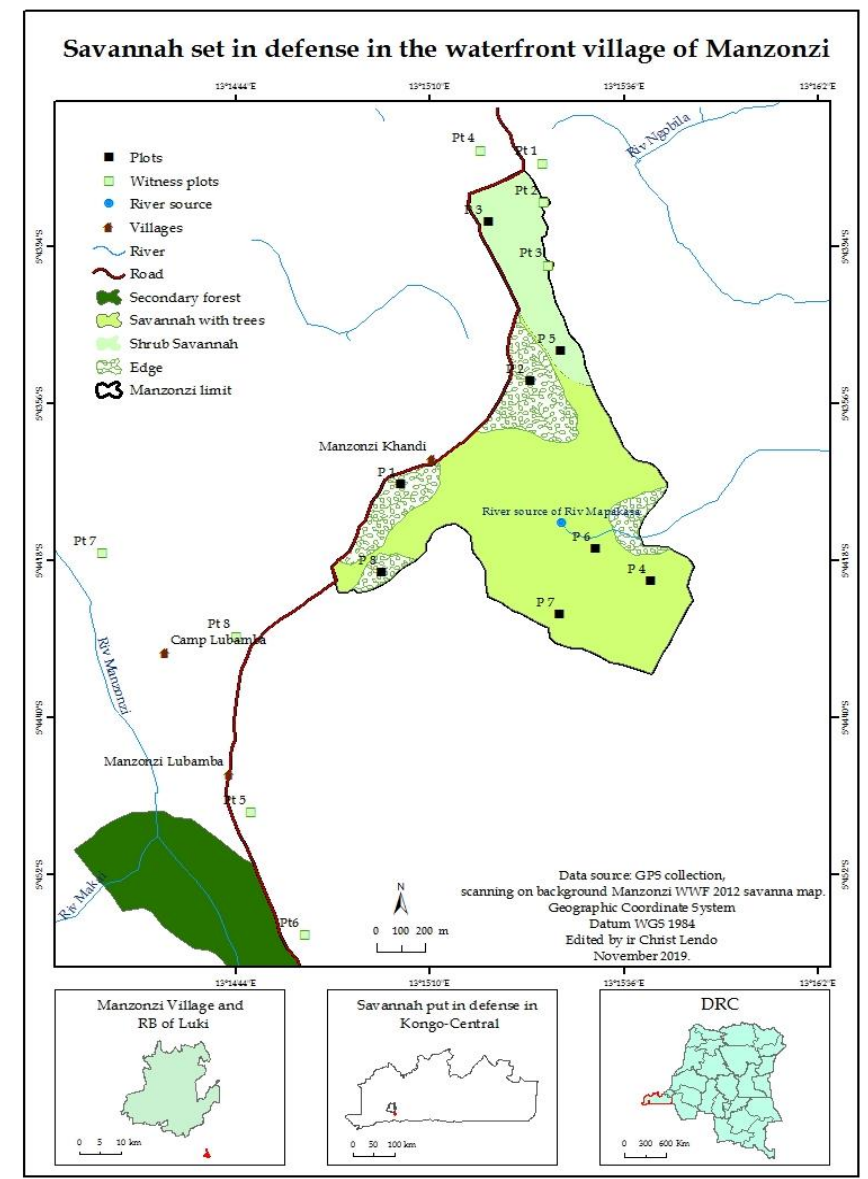

Figure 2. Layered inventory device in the savanna laid out in Manzonzi defenses

\section{Analytical and statistical approaches to the data}

Calculation of the volume of wood available

The calculation of the volume of wood is given by the formula of Rondeux (1993).

$$
V=G \times H \times f
$$

Where: $\mathrm{G}$ : basal area in $\mathrm{m}^{2}$, $\mathrm{H}$ : height in meter and $\mathrm{f}$ : form factor.

The calculation of the shape of the trees was essential to make more reliable the estimate of the volume of wood available in this savannah. This coefficient was obtained on trees taken as a model. Trees (templates) were selected to cut based on their straightness, to obtain a normal diametric decrease. Measurements of circumference were taken along the stem of the tree at intervals of $1 \mathrm{~m}$, whose reference circumference was that taken at $0 \mathrm{~m}$. Some trees were measured on feet without being cut, as they offered the possibility. For these model trees a series of coefficients was calculated according to the linear regression model: $1 / \mathrm{h}\left(\mathrm{x}_{1}{ }^{2}+\mathrm{x}_{2}{ }^{2}+\mathrm{x}_{3}{ }^{2}+\ldots \ldots . . \mathrm{x}_{\mathrm{n}}{ }^{2}\right)$, (Rondeux, 
1999); with h: the height of the tree, $X_{1}=$ circumference of segment $1, X_{2}=$ circumference of segment 2 etc. The shape coefficients thus obtained for each model tree are summed and a mean value is found for each species.

\section{Calculation of biomass and sequestered carbon}

To estimate the biomass of trees, we used the allometric equations developed by Malimbwi et al. (1994) for Miombo. This equation is described as follows:

$$
B=0.1 . D b h^{1.916} H^{0.74}
$$

Where B is biomass and Dhp is the diameter at chest height.

The Miombo are the wooded savannahs characteristic of the subtropical region of southern Africa (Ryan et al., 2011), which includes the south of the DRC biogeographically. This equation makes it possible to obtain the biomass of the stems and the roots of the trees. The results obtained in this work integrate the biomass and the carbon of the roots. Rate corresponding atoms were estimated by assuming that $50 \%$ of the biomass consists of carbon (Dupouey et al., 2002).

\section{Statistical analysis}

Statistical tests were based on the variance between the fire regime and the defenses. The main factor to be observed was the effect of defencion on savannas subject to the fire regime. The Fisher test (ANOVA) was the most appropriate because it had given satisfactory results. Variables taken into account were floristic diversity, density and volume of available wood, biomass and carbon. We used $\mathrm{R}$ version 2.10 .1 software (Cornillon et al., 2010) and the level of significance of the results retained is 0.05 and 0.0001 as appropriate.

\section{Results}

This section presents the results in terms of the volume of available wood and the treed areas of the trees in each plot of the savannah set aside and the SRF. The figures below present, among other things, the volume of wood from the different plots and plant formations in the defensive savannahs (SMD) and the savannahs under fire regime (SRF) (Figure 3); biomass in plots and plant formations at the level of SMD and SRF (Figure 4); carbon in plots and plant formations in the SMD and SRF (Figure 5).
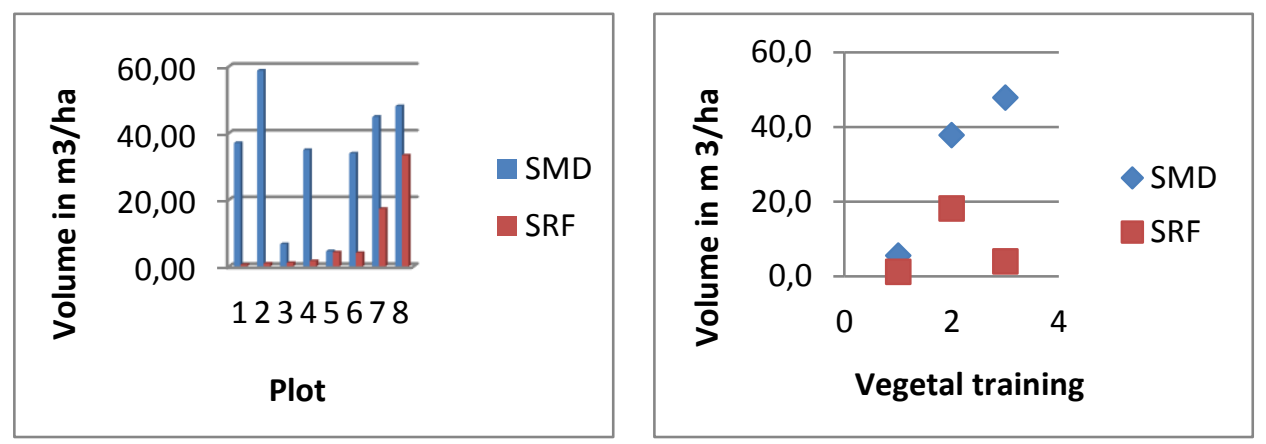

Figure 3. Wood volume of the plots and plant formations of the SMD and the SRF 

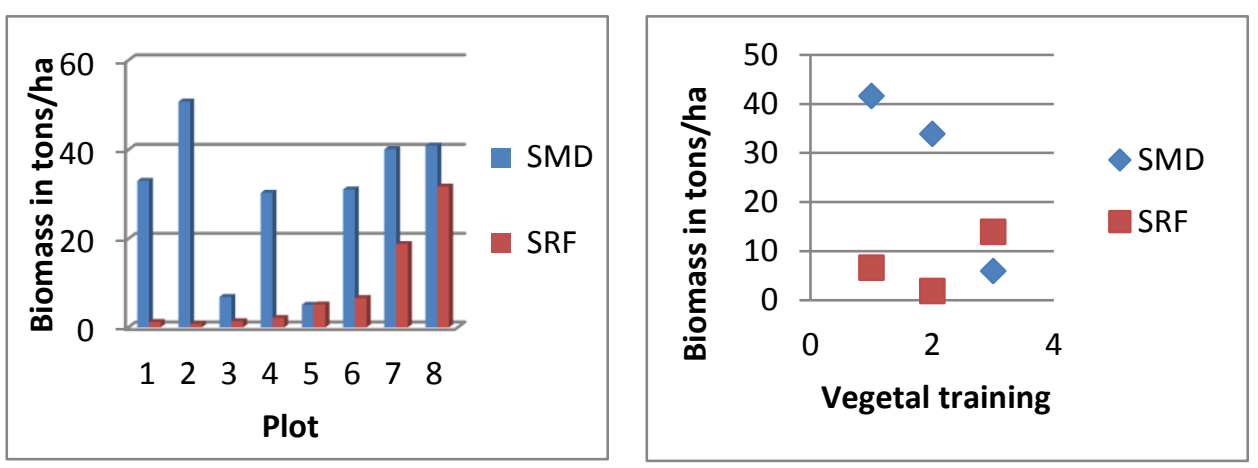

Figure 4. Biomass in the plots and plant formations of the SMD and in the SRF
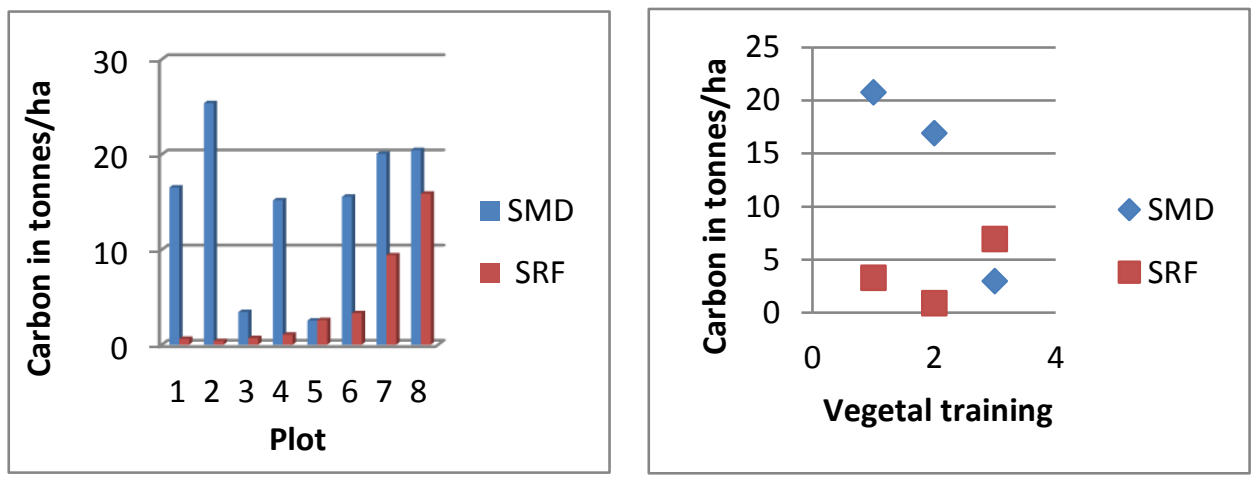

Figure 5. Sequestered carbon in the plots and plant formations of the SMD and in the SRF

\section{Statistical analysis}

The statistical analysis presents the volume of wood available, the biomass and the Carbon sequestered through the three figures below which show the dispersion of the volume values for the two landscape types including the SMD and the SRF (Figures 6, 7 and 8). It also presents in Table 1 below the summary of the diversity of the species as well as the frequency of the individual species displayed plot by plot in the SMD, and in Table 2 it summarizes the density data and certain variables related to the structure of vegetation, wood volume, biomass and sequestered carbon. In Appendices 1 and 2, the table summarizing the list of inventoried and defended species and the family structure of the savanna sub-plots put in defense.

Table 1. Species diversity and the frequency of the individual species displayed plot by plot in the SMD

\begin{tabular}{c|c|c}
\hline Plots & Diversity of species by plots & Frequencies \\
\hline Pt1 & 154 & $7.5 \%$ \\
Pt2 & 83 & $4.05 \%$ \\
Pt3 & 136 & $6.6 \%$ \\
Pt4 & 185 & $9.02 \%$ \\
Pt5 & 348 & $16.9 \%$ \\
Pt6 & 237 & $11.6 \%$ \\
Pt7 & 567 & $27.7 \%$ \\
Pt8 & 341 & $16.6 \%$ \\
\hline Total & $\mathbf{2 0 5 1}$ & \\
\hline
\end{tabular}


Table 2. Density of stand of the plots in the savannah put in defenses (SMD) and the savannah under fire regime ( $S R F)$

\begin{tabular}{c|c|c|c|c|c|c|c|c|c}
\hline Bloc & N.E. & N.F. & N.I. & $\begin{array}{c}\text { Mean } \\
\text { of_CHP } \\
(\mathbf{i n} \mathbf{~ c m})\end{array}$ & $\begin{array}{c}\text { Mean } \\
\text { of_height } \\
\text { (in m })\end{array}$ & $\begin{array}{c}\text { Mean of_G } \\
\left(\mathbf{m}^{2}\right)\end{array}$ & $\begin{array}{c}\text { Mean of_Vol } \\
\left(\mathbf{m}^{\mathbf{3}} \mathbf{)}\right.\end{array}$ & $\begin{array}{c}\text { Mean of_B } \\
\text { (tonne) }\end{array}$ & $\begin{array}{c}\text { Mean of_Cs } \\
\text { (tonne) }\end{array}$ \\
\hline Plot SMD 1 & 33 & 15 & 506 & $35.24 \pm 16.52$ & $6.25 \pm 3.23$ & $0.01 \pm 0.01$ & $0.07 \pm 0.21$ & $0.065 \pm 0.152$ & $0.032 \pm 0.075$ \\
Plot SMD 2 & 34 & 16 & 614 & $37.59 \pm 19.11$ & $6.73 \pm 3.83$ & $0.01 \pm 0.01$ & $0.09 \pm 0.22$ & $0.082 \pm 0.167$ & $0.041 \pm 0.083$ \\
Plot SMD 3 & 5 & 2 & 211 & $30.17 \pm 8.90$ & $5.26 \pm 2.10$ & $0.007 \pm 0.005$ & $0.03 \pm 0.03$ & $0.032 \pm 0.032$ & $0.016 \pm 0.016$ \\
Plot SMD 4 & 27 & 17 & 309 & $41.06 \pm 19.70$ & $7.44 \pm 3.94$ & $0.01 \pm 0.01$ & $0.11 \pm 0.21$ & $0.098 \pm 0.160$ & $0.049 \pm 0.080$ \\
Plot SMD 5 & 10 & 7 & 216 & $27.97 \pm 5.99$ & $4.69 \pm 1.43$ & $0.006 \pm 0.003$ & $0.02 \pm 0.02$ & $0.023 \pm 0.018$ & $0.011 \pm 0.009$ \\
Plot SMD 6 & 18 & 10 & 566 & $34.76 \pm 13.96$ & $6.21 \pm 2.81$ & $0.01 \pm 0.01$ & $0.05 \pm 0.12$ & $0.054 \pm 0.093$ & $0.027 \pm 0.046$ \\
Plot SMD 7 & 20 & 10 & 497 & $38.83 \pm 17.58$ & $7.02 \pm 3.52$ & $0.01 \pm 0.01$ & $0.09 \pm 0.16$ & $0.080 \pm 0.128$ & $0.040 \pm 0.064$ \\
Plot SMD 8 & 35 & 20 & 312 & $45.82 \pm 21.51$ & $8.49 \pm 4.22$ & $0.02 \pm 0.02$ & $0.15 \pm 0.26$ & $0.0131 \pm 0.204$ & $0.065 \pm 0.102$ \\
Plot SRF 1 & 8 & 5 & 154 & $20.59 \pm 0.45$ & $2.58 \pm 0.41$ & $0.003 \pm 0.000$ & $0.005 \pm 0.001$ & $0.007 \pm 0.004$ & $0.003 \pm 0.002$ \\
Plot SRF 2 & 6 & 5 & 83 & $21.78 \pm 0.24$ & $3 \pm 0$ & $0.003 \pm 8.550$ & $0.007 \pm 0.000$ & $0.009 \pm 0.0001$ & $0.004 \pm 0.0000$ \\
Plot SRF 3 & 8 & 5 & 136 & $22.73 \pm 0.45$ & $3 \pm 0.01$ & $0.004 \pm 0.000$ & $0.007 \pm 0.000$ & $0.010 \pm 0.004$ & $0.005 \pm 0.002$ \\
Plot SRF 4 & 9 & 6 & 185 & $24.19 \pm 0.51$ & $3 \pm 0$ & $0.004 \pm 0.000$ & $0.008 \pm 0.000$ & $0.011 \pm 0.004$ & $0.005 \pm 0.002$ \\
Plot SRF 5 & 8 & 5 & 346 & $26.75+1.00$ & $3.32 \pm 0.21$ & $0.005 \pm 0.000$ & $0.012 \pm 0.001$ & $0.014 \pm 0.001$ & $0.007 \pm 0.0008$ \\
Plot SRF 6 & 13 & 7 & 237 & $29.76 \pm 0.81$ & $3.91 \pm 0.13$ & $0.007 \pm 0.000$ & $0.017 \pm 0.002$ & $0.018 \pm 0.002$ & $0.009 \pm 0.001$ \\
Plot SRF 7 & 12 & 7 & 567 & $35.46 \pm 2.90$ & $4.68 \pm 0.42$ & $0.010 \pm 0.000$ & $0.030 \pm 0.007$ & $0.033 \pm 0.007$ & $0.016 \pm 0.003$ \\
\hline Plot SRF 8 & 12 & 7 & 341 & $51.06 \pm 9.47$ & $6.74 \pm 1.41$ & $0.021 \pm 0.009$ & $0.098 \pm 0.009$ & $0.093 \pm 0.053$ & $0.046 \pm 0.029$ \\
\hline
\end{tabular}

$\mathrm{NI}=$ Number of Individuals; $\mathrm{NE}=$ Number of species; $\mathrm{NF}=$ Number of Families; $\mathrm{CHP}=$ Breast Height Circumference; $\mathrm{G}=$ basal area; $\mathrm{B}=$ Biomass; $\mathrm{C}=$ sequestered carbon

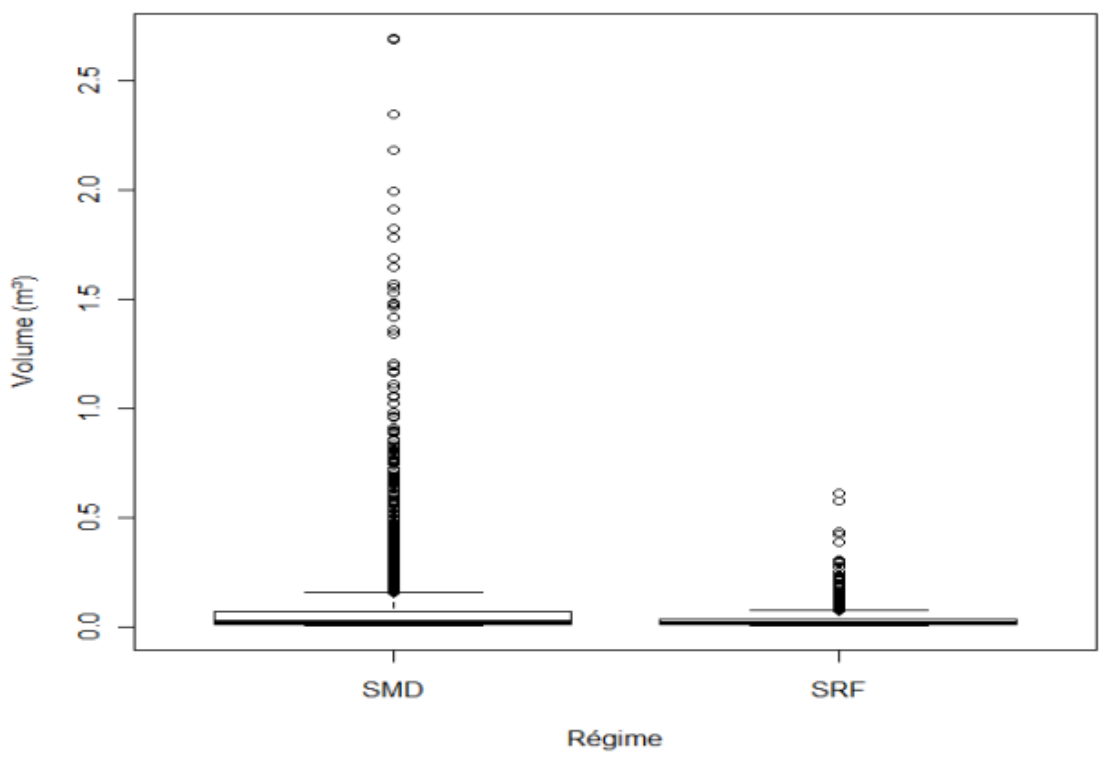

Figure 6. Dispersion of volume values for both schemes: $S M D$ and $S R F .(F=148.48$,

$$
P<0.0001)
$$




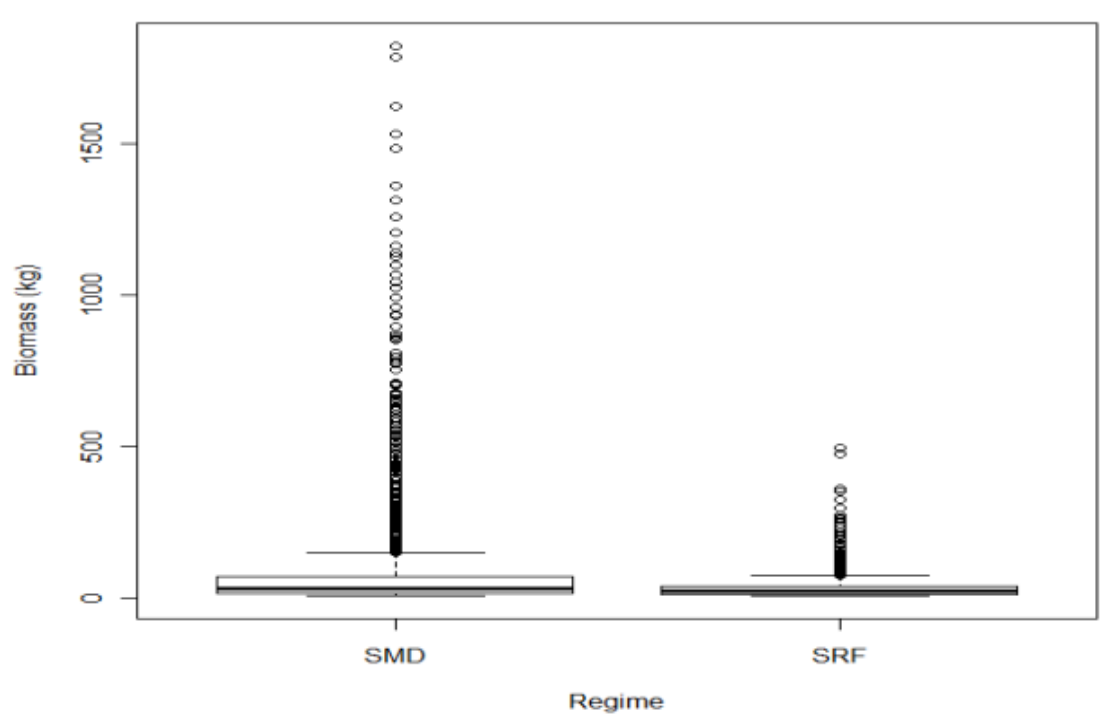

Figure 7. Dispersion of biomass for both schemes: SMD and SRF. $(F=167.36, P<0.0001)$

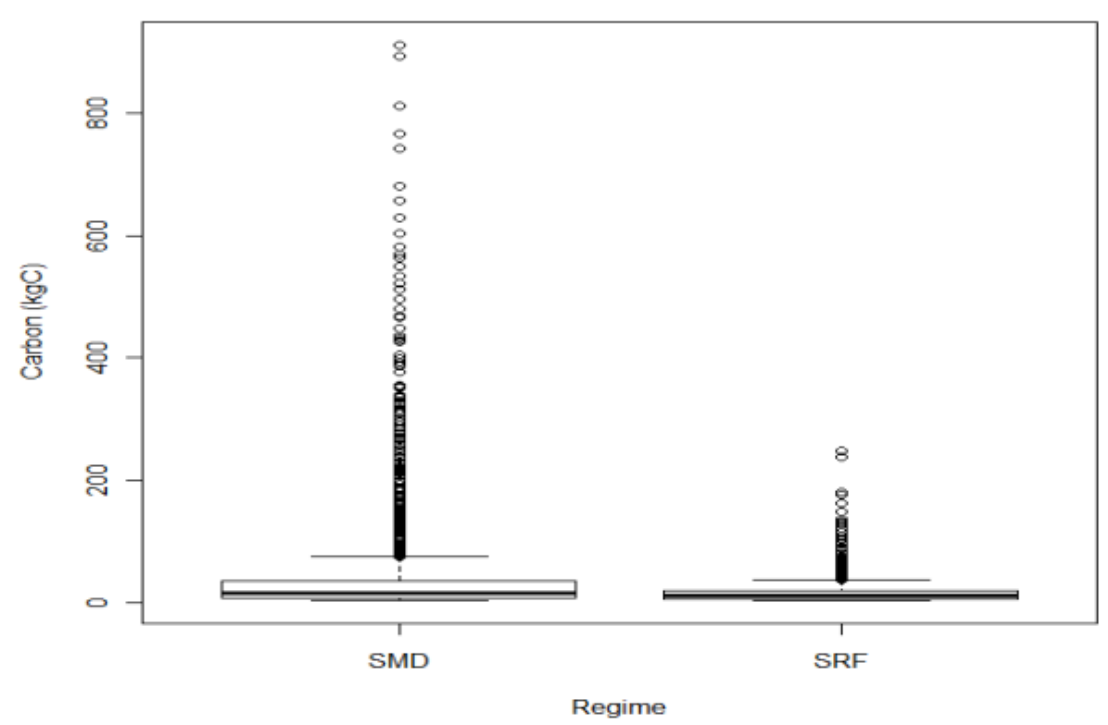

Figure 8. Dispersion of sequestered carbon for both schemes: SMD and SRF. $(F=167.36$, $P<0.0001)$

\section{Discussion}

In forestry, stands and their increments are usually expressed in wood volume. These volumes can be expressed by sintering or applying the cubic rate (Devineau, 1997). For our study, the volume of wood is obtained by the relation $V=G \times H \times f$ described in the methodology. The results of the study presented in Figures 3, 4 and 5 show that it is in SMD that there is a greater volume of wood plus biomass and carbon.

Statistically, the difference between SMD and SRF on volume of timber, biomass and carbon are very significant. We denote respectively $\mathrm{F}=148.48, \mathrm{P}<0.0001,167.36$, $\mathrm{P}<0.0001$ and 167.36, $\mathrm{P}<0.0001$. Figures 6,7 and 8 present the results of these analyzes and box plots represent $50 \%$ of the volume, biomass and carbon values. 
Carbon is the value of the biomass divided by two or 50\%, i.e. if in SMD we have 100 tons of biomass we will have 50 tons of carbon and if in SRF we have 25 tons of biomass we will have 12.5 tons of carbon. This means that the appearance of the biomass/carbon ratios will be the same (Figures 7 and 8). The dispersion is represented by the two mustache boxes. It is their comparison which gives the statistical result presented. Thick bars inside the boxes; bars below the volume, biomass and minimum carbon and the bar at the top of the box indicate the maximum value. It is also noted that many things are aberrant apart from mosquitoes which are actually individuals of reading, mean and great variability.

We note that the plots located in the edge (1,2 and 8) have higher volume, biomass and carbon. These values in terms of volume, biomass and carbon are generally superior to all the other plant formations present. In this plant formation, we find large trees whose circumference varies between 80 at $150 \mathrm{~cm}$. Then come the plots of wooded savannah (4,6 and 7). There is an increase in plot 7 which is due to its higher density (497 individuals) compared to the other two plots (309 and 366 individuals) of its category.

Plots 3 and 5 of the savannah set in the bush savanna are the poorest in terms of wood volume, biomass and carbon. The volume results obtained in plot 3 and 5 are low compared to the results of Devineau (1997) which obtained $18.2 \mathrm{~m}^{3} /$ ha in shrub savanna in Burkina Faso. It is in these plots (3 and 5) that we notice the greatest number of shrubs and the lowest density.

In the SRF, that are the plots in the savannah which a volume of wood, biomass and carbon higher than the two other vegetation. Pt7 and 8 are located in an area of Kraal that is covered by early fires in order to provide cattle with green grass during the dry season. The control plot located in the edge (Pt6) is poor in volume of wood, biomass and carbon due to its low density.

The results of Bellier et al. work (1969) made in a savannah with palmyra show rather that a savannah close to a forest can evolve towards a forest in spite of the action of the fire. The fact that the savanna in question is a savannah included in a forest block may be decisive in their conclusions. In SRF, plots 1, 2, 3 and 4 in bushland savannas such as SMD are very low in wood volume in biomass and carbon (Figures 3-5). We think that in addition to the action of fire there is the nature of the substrate (ferruginous) which can play an important role in the development of trees.

Specifically, Hymenocardia acida Tul., Anthocleista vogelii Planch, Albizia lebbeck (L.) Benth., Maprounea Africana Müll. Arg. are the most important species in terms of volume of wood, biomass and carbon in the SMD, while in the SRF they are Hymenocardia acida Tul., Maprounea Africana Müll. Arg and Bridelia ferruginea Benth, the most important species of Hymenocardia acida Tul. owes its place in this ranking due to its high density while Anthocleista vogelii Planch owes its place in this ranking following its rapid growth even though it has a low density. The results of our study showed that the savannah set in defense contains a higher volume of wood $\left(3.6 \mathrm{~m}^{3} / \mathrm{ha}\right)$ only in the bushfire savannah $\left(7.8 \mathrm{~m}^{3} / \mathrm{ha}\right)$.

In relation to biomass, SMD contains a biomass of $29.8 \mathrm{t} / \mathrm{ha}$ compared with $8.2 \mathrm{t} / \mathrm{ha}$. The sequestered carbon amounted to $14.9 \mathrm{tC} / \mathrm{ha}$ in the SMD, compared to $4.1 \mathrm{tC} / \mathrm{ha}$ in the SRF, which seems lower compared to the result obtained by Lubalega (2016) wich, in his work on the natural evolution of the savannahs defended at Ibivillage, on the Bateke plateau, in the Democratic Republic of Congo where it obtained average values of $107.477 \mathrm{t} /$ ha of total biomass, ie 51.05 megagram $(\mathrm{Mg}) \mathrm{C} / \mathrm{ha}$ in the gallery forest, 
$103,772 \mathrm{t} / \mathrm{ha}$ of total biomass is $49.29 \mathrm{Mg} \mathrm{C} / \mathrm{ha}$ in the forest island, and 22,336 $\mathrm{t} / \mathrm{ha}$ of total biomass is $10.60 \mathrm{Mg} \mathrm{C} /$ ha in the plantation.

The differences observed between the edge, the savannah and shrub savanna both in the SMD and in the SRF are due largely unlike their structure and their floristic composition. The averages obtained in the SMD in terms of volume, biomass and carbon are respectively $36 \mathrm{~m}^{3} / \mathrm{ha}, 28.8 \mathrm{t} / \mathrm{ha}$ and $14.4 \mathrm{t} / \mathrm{ha}$. According to Grace et al. (2006) Aboveground Carbon Stock in Savannas worldwide varies considerably depending on the extent of forest cover. It ranges from $1.8 \mathrm{tC} /$ ha where trees are absent to more than $30 \mathrm{tC} / \mathrm{ha}$ where tree cover is important. They claim that the average productivity of savannas from 1 to $12 \mathrm{tC} / \mathrm{ha} /$ year and that are lower values are mostly found in the savannahs dry and semi-arid who from most vast areas of Africa.

In our study, the carbon content (limited to ligneous species) after 6 years of protection is relatively low in some plots, especially shrub savanna. The results obtained in the edge (20.7 tC/ha) of the MDS are satisfactory compared to the results obtained in other countries. For example, Ryan et al. (2011) obtained $29.7 \mathrm{t} / \mathrm{ha}$ in miombo woodland in Mozambique. Ibrahima and Abib Fanta (2008) found in Ngaoundéré (Cameroon) that the quantity total carbon is of the order of 81.48 and $118.36 \mathrm{tC} / \mathrm{ha}$ respectively for the shrub and tree savanna. In the wooded savannah, most of the carbon is stored in the phytomass of trees $(65.30 \mathrm{tC} / \mathrm{ha})$ and in the ground $(48.37 \mathrm{tC} / \mathrm{ha})$; the contribution of shrubs $(3.83 \mathrm{t} / \mathrm{ha})$ herbaceous $(0.30 \mathrm{t} / \mathrm{ha})$, roots $(1.96 \mathrm{tC} / \mathrm{ha})$ and litters $(1.88 \mathrm{tC} / \mathrm{ha})$ is weak, less than $5 \%$ of total carbon. On the other hand, in the shrub savannah, soil is the main carbon reservoir $(74.35 \mathrm{tC} / \mathrm{ha})$. The other components namely shrubs $(0.66 \mathrm{tC} / \mathrm{ha})$, herbaceous plants $(3.15 \mathrm{tC} / \mathrm{ha})$, roots $(1.98 \mathrm{tC} / \mathrm{ha})$ and litters $(1.34$ $\mathrm{tC} / \mathrm{ha}$ ) have a very small contribution, less than $9 \%$ quantity total carbon. Mushini et al. (2010) obtained 19.2 tC/ha in their work in wooded areas of Miombo Woodlands of the Southern Highland from the Republic of Tanzania.

\section{Conclusion and suggestions}

The objective of this paper was to evaluate the effects of savanna protection under fire regime, savanna productivity (biomass and wood volume) and sequestered carbon, and to analyze and compare the productivity and carbon content of woody savannah vegetation with that of savannas subject to the fire regime of different intensity, and to demonstrate the ecological benefits of savanna conservation in relation to climate.

In terms of productivity (biomass, carbon and wood volume), this study found that SMD was more productive than SRF and that species such as, Hymenocardia acida Tul., Anthocleista vogelii Planch, Albizia lebbeck (L.) Benth., Maprounea africana Müll. Arg. are the most important species in terms of the volume of available wood, biomass and carbon in the MSD, while in the SRF they are Hymenocardia acida Tul., Maprounea africana Müll. Arg. and Bridelia ferruginea Benth, the most important species.

One of the objectives of the defense of savannah is to restore the vegetation cover and increase the diversity in the areas considered by using fire which is a means of protecting savannah against fire over wide areas. In terms of biodiversity, we attest that the protection of savannas is an effective way to restore vegetation cover, increase productivity and biodiversity in an ecosystem. It allows the developments of organisms adapted to the ecological conditions of the environment and allow the ecosystem to evolve towards the climax, unlike reforestation with these exotic species. Muys (2007) argues that local communities often opt for fast-growing exotic trees, but in the name of restoring biodiversity, it is preferable that they replant indigenous species that carry 
with them a procession of trees organizations that have coevolved. In addition, these native species have a wood often denser which compensates, at least partially, their lower growth in volume. Beyer et al., 2007 state that the average temperature increase is expected to be about 0.1 to $0.4 \%$ per decade. The protection of savannas is one of the effective means of helping to regulate the climate at the local scale because the forest cover it creates leads to a decrease in albedo (warming), but at the same time a higher evapotranspiration (cooling) and recycling of rainwater (Silver and Defries, 1990).

Tropical forests are known to play an important role in cooling the global climate by immobilizing carbon (Puig, 2001), and by their high evapotranspiration capacity. The protection of savannas can not only contribute to increasing the forest area (if successful) but also contributes effectively to the overall services provided to the environment.

Based on the above, we suggest:

- Popularize the defensive technique used in this study to help expand forest areas and promote the conversion of shrubby savannas to forest while increasing the possibilities of access to ecosystem services (climate regulation, water cycle, service supply and ecological habitat).

- Ensure the increase of the basal area thus increasing the richness and the specific diversity of two formations, thus reflecting natural reforestation.

- Take into account in the future the assessment of the biomass of grasses as well as scrubland because these are as important as the woody species in the case of this typical savannah.

- Conduct analytical studies of soils in different plant formations and / or plots of the SMD, to further explain the flora they display.

- Ensure significant forest regeneration by planting fast-growing tree species that can in the near future show an expansion of the forest that will contribute to increasing carbon storage areas and increasing the amount of carbon in different compartments or reservoirs (wells) of the savannah ecosystem (aboveground biomass, belowground biomass, in dead wood, litter and soil).

- Install plots at the savanna edge interface to assess the rate of savannah colonization by edge features.

- Continue to support local populations by multiplying projects and incomegenerating activities promoting development in order to free them from the total dependence of forest products.

- Increase awareness.

\section{REFERENCES}

[1] Ahlström, A., Raupach, M. R., Schurgers, G., Smith, B., Arneth, A., Jung, M., Reichstein, M., Canadell, J. G., Friedlingstein, P., Jain, A. K., Kato, E., Poulter, B., Sitch, S., Stocker, B. D., Viovy, N., Wang, Y. P., Wiltshire, A., Zaehle, S., Zeng, N. (2015): The dominant role of semi-arid ecosystems in the trend and variability of the land $\mathrm{CO} 2$ sink. - Science 348: 895-899. https://doi.org/10.1126/science.aaa1668.

[2] Beer, C., Reichstein, M., Tomelleri, E., Ciais, P., Jung, M., Carvalhais, N., Rodenbeck, C., Arain, M. A., Baldocchi, D., Bonan, G. B., Bondeau, A., Cescatti, A., Lasslop, G., Lindroth, A., Lomas, M., Luyssaert, S., Margolis, H., Oleson, K. W., Roupsard, O., Veenendaal, E., Viovy, N., Williams, C., Woodward, F. I., Papale, D. (2010): Terrestrial gross carbon dioxide uptake: global distribution and covariation with climate. - Science 329: 834-838. https://doi.org/10.1126/science.1184984. 
[3] Bellier, L., Gillon, D., Gillon, Y., Guillaumet, J. L., Perraud, A. (1969): Research on the origin of a savanna included in the lower Cavally forest block (Ivory Coast) by the study of soils and biocenosis. - Cahor Orstom, Sér.Biol. No.10, 30 p.

[4] Beyer, G., Defays, M., Fisher, M., Fletcher, J., Munck, E. D., Jaeger, F. D., Riet, C. V., Vandeweghe, K., Wijnendaele Gonze, C., Guy, J. C., Coutrot, D. (2007): Fight against climate change: use the wood. - Wood in sustainable development. Brussels, Belgium, 84 p.

[5] Bombelli, A., Henry, M., Castaldi, S., Adu-Bredu, S., Arneth, A., De Grandcourt, A., Grieco, E., Kutsch, W. L., Lehsten, V., Rasile, A., Reichstein, M., Tansey, K., Weber Valentini, R. (2009): The Sub-Saharan Africa carbon balance, an overview. - Biosciences Discussions 6: 2085-2123.

[6] Brando, P. M., Balch, J. K., Nepstad, D. C., Morton, D. C., Putz, F. E., Coe, M. T., Silverio, D., Macedo, M. N., Davidson, E. A., Nobrega, C. C., Alencar, A., Soares-Filho, B. S. (2014): Abrupt increases in Amazonian tree mortality due to droughtfire interactions. - P. Natl. Acad. Sci. USA 111: 6347-6352. https://doi.org/10.1073/pnas.1305499111.

[7] Brown, S., Gillespie, A. J., Lugo, A. E. (1989): Biomass estimation methods for tropical forests with applications to forest inventory data. - Forest Science 35: 881-902.

[8] Chidumayo, E. N. (1988): Estimating fuelwood production and yield in regrowth dry miombo woodland in Zambia. - Forest Ecology and Management 24: 59-66.

[9] Clément, J. (1982): Estimation of volumes and productivity of mixed tropical forest and grass formations. Data on francophone African countries in northern Ecuador and recommendations for conducting new studies. - Magazines Tropical Woods and Forests 198 (4), 24 p.

[10] Cornillon, P. A., Guyader, A., Husson, F., Jegou, N., Josse, J., Kloareg, M., Matzner, L. E., Rouviere, L. (2010): Stat with R. 2nd augmented edition. - Presses Universitaires de Rennes, French statistical society, 274 p.

[11] Dayton, B. F. (1978): Standing crops of dominant Combretum species at three browsing levels in the Kruger National Park. - Koedoe 21: 67-76.

[12] Deshmukh, I. (1992): Estimation of wood biomass in the Jubba Valley, southern Somalia, and its application to East African rangelands. - African Journal of Ecology 30: 127-136.

[13] Devineau, J. L., Lecordier, C., Vuattoux, R. (1984): Evolution of the specific diversity of the woody stand in a pre-forest succession of colonization of a savannah protected from fire (Lamto, Ivory Coast). - Available at: http://hal.archives-ouvertes.fr/docs/00/43/49/47/PDF/Devineau_et_al_1984.pdf.

[14] Devineau, J. L. (1997): Seasonal evolution and rate of increase of basal areas of ligneous trees in some Sudanese savannah stands in western Burkina Faso. - Ecology 28(3): 217232.

[15] Dias, A. T. C., De Mattos, E. A., Vieira, S. A., Azeredo, J. V., Sacarano, F. R. (2006): Aboveground biomass stocks of native woodland on a Brazilian sandy coastal plain: estimates based on the dominant tree species. - Forest Ecology and Management 226: 364-367.

[16] Dibi, N., Cya, Y., Ne, K., Kone, M., Yao, S. C. (2008): Analysis of the floral diversity of the Marahoué National Park, Central West of Ivory Coast. - Africa science 4(3): 552-579.

[17] Duarte. L. da S., Dos-Santos, M. M. G., Hartz, S. M., Pillar, V. D. (2006): Role of nurse plants in Araucaria Forest expansion over grassland in south Brazil. - Austral Ecology 31(4): 520-528.

[18] Dupouey, J. L., Pignard, G., Badge, V., Thimonier, A., Dhote, J. F., Nepveu, G., Berges, L., Augusto, L., Belkacem, S., Nys, C. (2002): Stock and carbon flux in French forests. Proceedings of the Academy of Agriculture of France. INRA, Paris, $16 \mathrm{p}$.

[19] Eaton, J. M., Lawrence, D. (2009): Loss of carbon sequestration potential after several decades of shifting cultivation in the southern Yucatán. - Forest Ecology and Management 258: 949-958.

[20] Favier, C., De Namur, C., Dubois, M. A. (2004): Forest progression modes in littoral Congo, Central Atlantic Africa. - Journal of Biogeography 31: 1445-1461. 
[21] Favrichon, V., Gourlet-Fleury, S., Barhen, A., Dessart, H. (1998): Permanent plots in dense rainforest. Element for a data analysis methodology. - CIRAD - Forêt Campus International of Baillarquet. FORAFRI 1998 series document 14, 30432 Montpellier Cedex 1, France, 67 p.

[22] Giannecchini, M., Twine, W., Vogel, C. (2007): Land-cover change and humanenvironment interactions in a rural cultural landscape in South Africa. - Geographical Journal 173: 26-42.

[23] Grace, J., San Jose, J., Meir, P., Miranda, H. S., Montes, R. A. (2006): Productivity and carbon fluxes of tropical savannas. - Journal of Biogeography 33: 387-400.

[24] Hofstad, O. (2005): Review of biomass and volume function for individual trees and shrubs in southeast Africa. - Journal of Tropical Forest Science 17: 151-162.

[25] Ibrahima, A., Abib Fanta, C. (2008): Estimation of the carbon stock in the wooded and shrubby facies of the Sudano-Guinean savannahs of Ngaoundéré, Cameroon. - Cameroon newspaper of experimental biology 4(3): 1-11.

[26] Jacquin, A. (2010): Dynamics of savanna vegetation in relation to the use of fires in Madagascar. Time series analysis of remote sensing images. - Thesis in order to obtain the doctorate of the University of Toulouse. $146 \mathrm{p}$.

[27] Kapa, B., Nkiama, M., Malele, M., Ritvisay, M. (1987): Development of the Luki Biosphere Reserve. - SPIAF, $67 \mathrm{p}$.

[28] Kelly, R. D., Walker, B. H. (1977): The effects of different forms of land use on the ecology of a semi-arid region in south-eastern Rhodesia. - Journal of Ecology 64: 553576.

[29] Lal, R. (2002): Carbon sequestration in dryland ecosystems of West Asia and North Africa. - Land Degradation \& Development 13: 45-59.

[30] Liu, Y. Y., van Dijk, A. I. J. M., de Jeu, R. A. M., Canadell, J. G., McCabe, M. F., Evans, J. P., Wang, G. (2015): Recent reversal in loss of global terrestrial biomass. - Nat. Clim. Change 5: 470-474. https://doi.org/10.1038/nclimate 2581.

[31] Lubalega, T. (2016): Natural evolution of the savannahs defended at Ibivillage, on the Bateke plateau, in the Democratic Republic of Congo. - Joint thesis Université Laval / Québec, Canada / Philosophiae doctor (Ph.D.).

[32] Lubini, A. (1997): Vegetation of the Luki Biosphere Reserve in Mayombe (Zaire). Opera botanica Belgica 10. Garden Botanical National of Belgium, Meise, 155 p.

[33] Malhi, Y., Roberts, J. T., Betts, R., Killeen, T. J., Li, W., Nobre, C. (2008): Climate Change, Deforestation, and the Fate of the Amazon. - Science 319: 169-172.

[34] Malimbwi, R. E., Solberg, B., Luoga, E. (1994): Estimation of biomass and volume in miombo woodland at Kitulangalo Forest Reserve, Tanzania. - Journal of Tropical Forest Science 7(2): 230-242.

[35] Manlay, R., Peltier, R., N'Toupka, M., Gautier, D. (2002): Assessment of the tree resources of a Sudanese savannah village in North Cameroon for sustainable management. - In: Jamin, J. Y., Seiny Boukar, L. (eds.) Symposium "African savannahs: changing spaces, actors facing new challenges." 27-31 May 2002. PRASAC, Garoua, Cameroon. in C.D. Rom.

[36] Miles, L., Kapos, V. (2008): Reducing greenhouse gas emission from deforestation and forest degradation: global land-use implications. - Science 320: 1454-1455.

[37] Mills, A. J., Cowling, R. M., Fey, M. V., Kerley, G. I. H., Lechmere-Oertel, R. G., Sigwela, A., Skowno, A., Rundel, P. W. (2005): Effects of goat pastoralism on ecosystem carbon storage in semi-arid thicket, Eastern Cape, South Africa. - Austral Ecology 30: 807-813.

[38] Mills, A. J., Cowling, R. M. (2006): Rate of carbon sequestration at two thicket restoration sites in the Eastern Cape, South Africa. - Restoration Ecology 14: 38-49.

[39] Munishi, P. K. T., Mringi, S., Shirima, D. D., Linda, S. K. (2010): The role of the Miombo Woodlands of the Southern Highlands of Tanzania as carbon sinks. - Journal of Ecology and the Natural Environment 2(12): 261-269. 
[40] Muys, B. (2007): The importance of tropical forests in carbon sequestration and climate management. - Science Connection 18: 15-18. Brussels, Belgium.

[41] Pan, Y., Birdsey, R. A., Fang, J., Houghton, R., Kauppi, P. E., Kurz, W. A., Phillipps, O. L., Shvidenko, A. Z., Lewis, S. L., Canadell, J. G., Ciais, P., Jackson, R. B., Pacala, S. W., McGuire, A. D., Piao, S., Rautiainen, A., Sitch, S., Hayes, D. (2011): A Large and Persistent Carbon Sink in the World's Forests. - Science 333(6045): 988-993.

[42] Powell, M. J. (2008): Restoration of degraded subtropical thickets in the Baviaanskloof Megareserve, South Africa: the role of carbon stocks and Portulacaria afra survivorship. MSc Thesis, Rhodes University, Grahamstown, 144 p.

[43] Puig, H. (2001): The tropical rainforest. - Editions Belin, Saint-Amand-Montrond, France, ISBN 2-7011-2446-8, $447 \mathrm{p}$.

[44] Quinif, Y. (1986): Genesis of karts in tows in intertropical countries the example of Bas Zaire. - Annale of the Geological Society of Belgium 109: 515-527.

[45] Rondeux, J. (1993): The measurement of trees and forest stands. - $1^{\text {st }}$ edition, Gembloux, Belgium: Agronomic Press of Gembloux, $522 \mathrm{p}$.

[46] Rondeux, J. (1999): The measurement of trees and forest stands. $-2^{\text {nd }}$ edition, Gembloux, Belgium: Agronomic press of Gembloux, $521 \mathrm{p}$.

[47] Ryan, C. M., Williams, M., Grace, J. (2011): Above-and Belowground Carbon Stocks in Miombo Woodland Landscape of Mozambique. - Biotropica 43(4): 423-432.

[48] Salis, S. M., Assis, M. A., Mattos, P. P., Pião, A. C. S. (2006): Estimating aboveground biomass and wood volume of a savanna woodland in Brazil's Panatal wetlands based on allometric correlations. - Forest Ecology and Management 228: 61-68.

[49] Scholes, R. J., Hall, D. O. (1996): The carbon budget of tropical savannas, woodlands and grasslands. - In: Breymeyer, A. I., Hall, D. O., Melillo, J. M., Agren, G. I. (eds.) Global Change: Effects on Coniferous Forests and Grasslands. John Wiley \& Sons, Chichester, UK, pp. 69-99.

[50] Shackleton, C. M., Scholes, R. J. (2010): Above ground woody community attributes, biomass and carbon stocks along a rainfall gradient in the savannas of the central lowveld, South Africa. - South African Journal of Botany 77(1): 184-192.

[51] Silver, C. S., DeFries, R. (1990): A planet, a future. - National Academy of Sciences, New Horizons, Washington DC, USA, 189 p.

[52] Solbrig, O. T., Menaut, J. C., Mentis, M., Shugart, H. H., Stott, P., Wigston, D. (1991): Savanna modelling for global change. - Biology International 24.

[53] SPIAF (2007): Forest management inventory standards. Operational guide. - Ministry of Environment, Conservation of Nature and Tourism. 33 p.

[54] Sys, C. (1960): Soil and vegetation map of the Belgian Congo and Rwanda-Urundi, explanatory note of the soil map of the Belgian Congo and Rwanda-Urundi. Publications of the National Institute for Agronomic Study of the Belgian Congo (INEAC.) A. R. of 22-12-33 and 21-12-39, Brussels, 96 p.

[55] Tietema, T. (1993): Biomass determination of fuelwood trees and bushes of Botswana, southern Africa. - Forest Ecology and Management 60: 257-269.

[56] Trugman, A. T., Medvigy, D., Hoffmann, W. A., Pellegrini, A. F. A. (2018): Sensitivity of woody carbon stocks to bark investment strategy in Neotropical savannas and forests. - Biogeosciences 15(1).

[57] van der Werf, G. R., Morton, D. R., DeFries, R. S., Olivier, J. G. J., Kasibhatla, P. S., Jackson, R. B., Randerson, J. T. (2009): $\mathrm{CO}_{2}$ emissions from forest loss. - Nat. Geosci. 2: 737-738.

[58] van der Werf, G. R., Randerson, J. T., Giglio, L., Collatz, G. J., Mu, M., Kasibhatla, P. S., Morton, D. C., DeFries, R. S., Jin, Y., van Leeuwen, T. T. (2010): Global fire emissions and the contribution of deforestation, savanna, forest, agricultural, and peat fires (19972009). - Atmos. Chem. Phys. 10: 11707-11735. https://doi.org/10.5194/acp-10-117072010. 
[59] Williams, M., Ryan, C. M., Rees, R. M., Sambane, E., Fernando, J., Grace, J. (2008): Carbon sequestration and biodiversity of re-growing miombo woodlands in Mozambique. - Forest Ecology and Management 254: 145-155.

[60] Woomer, P. L., Touré, A., Sall, M. (2004): Carbon stock in Senegal's transition zone. Journal of Arid Environments 59: 499-510.

\section{APPENDIX}

Appendix 1. List of inventoried and defended species

\begin{tabular}{|c|c|c|c|}
\hline Species & $\begin{array}{l}\text { Number of Dhp } \\
\text { (in cm) }\end{array}$ & $\begin{array}{l}\text { Number of Chp } \\
\text { (in cm) }\end{array}$ & $\begin{array}{c}\text { Number of Height } \\
\text { (in m) }\end{array}$ \\
\hline Albizia ferruginea (Guill. \& Perr.) Benth. & 9 & 9 & 9 \\
\hline Albizia gummifera (J.F. Gmel.) C.A. Sm. & 13 & 13 & 13 \\
\hline Albizia lebbeck (L.) Benth. & 197 & 197 & 197 \\
\hline Alchornea cordifolia (Schumach. \& Thonn.) Müll. Arg. & 8 & 8 & 8 \\
\hline Annona senegalensis Pers. & 48 & 48 & 48 \\
\hline Anthocleista vogelii Planch & 159 & 159 & 159 \\
\hline Antiaris toxicaria Lesch. & 3 & 3 & 3 \\
\hline Barteria nigritiana Hook.f. & 6 & 6 & 6 \\
\hline Blighia welwitschii (Hiern) Radlk. & 1 & 1 & 1 \\
\hline Bridelia atroviridis Müll. Arg. & 1 & 1 & 1 \\
\hline Bridelia ferruginea Benth. & 175 & 175 & 175 \\
\hline Canarium schweinfurthii Engl. & 1 & 1 & 1 \\
\hline Canthium oddonii (De Wild.) C. Evrard & 21 & 21 & 21 \\
\hline Chrysophyllum africanum A. DC. & 2 & 2 & 2 \\
\hline Corynanthe paniculata Welw. & 3 & 3 & 3 \\
\hline Crossopteryx febrifuga (Afzel. ex G. Don) Benth. & 20 & 20 & 20 \\
\hline Crossopteryx $s p$ & 27 & 27 & 27 \\
\hline Croton sylvaticus Hochst. ex Krauss & 10 & 10 & 10 \\
\hline Dacryodes buettneri (Engl.) H. J. Lam & 7 & 7 & 7 \\
\hline Deinbolia acuminata Exell & 5 & 5 & 5 \\
\hline Dracaena mannii (Willd.) Link & 1 & 1 & 1 \\
\hline Eriocoelum microspermum Radlk. ex De Wild. & 1 & 1 & 1 \\
\hline Ficus mucuso Welw. ex Ficalho & 1 & 1 & 1 \\
\hline Ficus recurvata De Wild. & 8 & 8 & 8 \\
\hline Harungana madagascariensis Lam. ex Poir. & 5 & 5 & 5 \\
\hline Holarrhena congolensis Stapf & 11 & 11 & 11 \\
\hline Hymenocardia acida Tul. & 786 & 786 & 786 \\
\hline Hymenocardia ulmoides Oliv. & 39 & 39 & 39 \\
\hline Lannea welwitschii (Hiern) Engl. & 140 & 140 & 140 \\
\hline Macaranga monandra Müll. Arg. & 32 & 32 & 32 \\
\hline Macaranga spinosa Müll. Arg. & 386 & 386 & 386 \\
\hline Maesopsis eminii Engl. & 10 & 10 & 10 \\
\hline Maprounea africana Müll. Arg. & 535 & 535 & 535 \\
\hline Markhamia sessilis Sprague & 21 & 21 & 21 \\
\hline Microdesmis puberula Hook. f. ex Planch. & 1 & 1 & 1 \\
\hline Millettia versicolor Welw. ex Baker & 61 & 61 & 61 \\
\hline Monodora myristica (Gaertn.) Dunal & 6 & 6 & 6 \\
\hline Morinda lucida Benth. & 1 & 1 & 1 \\
\hline Musanga cecropioides $\mathrm{R}$. Br. ex Tedlie & 1 & 1 & 1 \\
\hline Myrianthus arboreus P. Beauv. & 1 & 1 & 1 \\
\hline Nauclea latifolia Smith & 167 & 167 & 167 \\
\hline Ochna afzelii R. Br. ex Oliv. & 4 & 4 & 4 \\
\hline Oncoba welwitschii Oliv. & 100 & 100 & 100 \\
\hline Piptadeniastrum africanum (Hook.f.) Brenan & 1 & 1 & 1 \\
\hline Pseudospondias microcarpa (A. Rich.) Engl. & 7 & 7 & 7 \\
\hline Pteleopsis hylodendron Mildbr. & 7 & 7 & 7 \\
\hline Symphonia globulifera L. f. & 2 & 2 & 2 \\
\hline
\end{tabular}




\begin{tabular}{c|c|c|c}
\hline Species & $\begin{array}{c}\text { Number of Dhp } \\
\text { (in cm) }\end{array}$ & $\begin{array}{c}\text { Number of Chp } \\
\text { (in cm) }\end{array}$ & $\begin{array}{c}\text { Number of Height } \\
\text { (in m) }\end{array}$ \\
\hline Tetrochidium didymonstemon (Baill.) Pax \& K. Hoffm. & 40 & 40 & 40 \\
Trema orientalis (L.) Blume & 9 & 9 & 9 \\
Trichilia gilgiana Harms & 4 & 4 & 4 \\
Trilepsium madagascariense Thouars ex DC. & 4 & 4 & 4 \\
Vernonia conferta Benth. & 3 & 3 & 3 \\
Vismia affinis Oliv. & 2 & 2 & 2 \\
Vitex madiensis Oliv. & 9 & 9 & 9 \\
Xylopia aethiopica Dunal A. Rich. & 71 & 71 & 71 \\
Xylopia chrysophylla Louis ex Boutique & 20 & 20 & 20 \\
Zanthoxylum gilletii (De Wild.) P.G.Waterman & 18 & 18 & 18 \\
\hline Total général & $\mathbf{3 2 3 1}$ & $\mathbf{3 2 3 1}$ & $\mathbf{3 2 3 1}$ \\
\hline
\end{tabular}

$\mathrm{CHP}=$ Breast Height Circumference

Appendix 2. Family structure in the savannah sub-parcels put in defense

\begin{tabular}{c|c|c|c|c|c}
\hline Number & Families & N.E. & N.I. & DIR & DER \\
\hline 1 & Euphorbiaceae & 5 & 331 & 19.2 & 38.5 \\
2 & Fabaceae & 5 & 39 & 19.2 & 4.5 \\
3 & Annonaceae & 3 & 214 & 11.5 & 24.9 \\
4 & Rubiaceae & 3 & 144 & 11.5 & 16.8 \\
5 & Apocynaceae & 1 & 5 & 3.8 & 0.6 \\
6 & Bignogniaceae & 1 & 2 & 3.8 & 0.2 \\
7 & Burseraceae & 1 & 1 & 3.8 & 0.1 \\
8 & clusiaceae & 1 & 30 & 3.8 & 3.5 \\
9 & Compositae & 1 & 11 & 3.8 & 1.3 \\
10 & Flacourtiaceae & 1 & 42 & 3.8 & 4.9 \\
11 & Gentianaceae & 1 & 32 & 3.8 & 3.7 \\
12 & Meliaceae & 1 & 1 & 3.8 & 0.1 \\
13 & Passifloraceae & 1 & 4 & 3.8 & 0.5 \\
14 & Rutaceae & 1 & 3 & 3.8 & 0.3 \\
\hline
\end{tabular}

$\mathrm{NI}=$ Number of individuals; NE = Number of species; DIR = Relative Diversity; DER = Relative density 